\title{
COMUNICAÇÃ̃O
}

[Communication]

\section{Ocorrência de Giardia spp. em bezerros leiteiros no Brasil}

[Occurrence of Giardia spp. in dairy calves in Brazil]

\author{
A.M. Guimarães ${ }^{1}$, E. Guedes ${ }^{2}$, R.A. Carvalho ${ }^{2}$ \\ ${ }^{1}$ Departamento de Medicina Veterinária da Universidade Federal de Lavras \\ Caixa Postal 37 \\ 37.200-000 - Lavras, MG \\ ${ }^{2}$ Acadêmico do Curso de Medicina Veterinária, UFLA, bolsista do CNPq/PIBIC
}

Recebido para publicação em 9 de outubro de 2000
E-mail: amg@ufla.br

Giardia spp. constitui um dos principais parasitos intestinais do homem e dos animais (Adam, 1991), freqüentemente associado com a ocorrência de diarréia (Kirkpatrick, 1987; Zajac, 1992). Apesar de escassos estudos na espécie bovina, alguns trabalhos têm demonstrado o envolvimento desse protozoário na ocorrência de diarréia em bezerros, de forma isolada ou associada com outros enteropatógenos (Xiao et al., 1993; Xiao et al., 1994; Olson et al., 1997). O objetivo desta nota é divulgar a ocorrência de cistos de Giardia em fezes de bezerras lactentes em uma propriedade particular com sistema intensivo de produção de leite, localizada no município de Lavras, Minas Gerais. Neste estudo foram utilizadas 50 bezerras da raça Holandesa, lactentes (1 a 90 dias de idade), criadas sob condições semelhantes de manejo. Os animais foram mantidos em piquetes, em sistema de abrigos individuais, periodicamente remanejados de local. Usou-se aleitamento artificial complementado com ração balanceada e sal mineral. Após desmama, realizada aos 90 dias de idade, os animais foram transferidos para novos piquetes. Entre março de 1999 e abril de 2000, semanalmente, foram coletadas amostras de fezes de cada bezerra diretamente da ampola retal. No final foram coletadas 120 amostras. Para o exame de cistos de Giardia, utilizaram-se amostras de fezes contendo oocistos de Eimeria spp. colocados para esporular em solução de dicromato de potássio a $2,5 \%$ à temperatura ambiente por uma a duas semanas. As amostras de fezes foram colocadas em tubo de centrífuga, completando-se o volume até a borda com solução de sulfato de zinco a 33\%, com uma lamínula apoiando-se sobre a solução. O material foi centrifugado a 2000rpm durante 10 minutos e as lamínulas examinadas em microscópio óptico (400X). Os exames foram realizados no Laboratório de Parasitologia do Departamento de Medicina Veterinária da Universidade Federal de Lavras. Antes de se proceder aos exames parasitológicos classificava-se a consistência fecal de acordo com o aspecto macroscópico em fezes firmes, pastosas, líquidas e semi-líquidas, de acordo com Dirksen et al. (1993). As fezes líquidas e semi-líquidas foram consideradas diarréicas e as normais, firmes ou pastosas, como fezes sem diarréia. Cistos de Giardia spp. foram observados em 9\% (11/120) das amostras fecais. A média de idade dos animais infectados foi de $30 \pm 19$. Nove animais (82\%) infectados com Giardia também eliminaram oocistos de Cryptosporidium spp. nas fezes. Diarréia foi observada em $36 \%$ (4/11) das bezerras infectadas com Giardia, quando elas tinham entre 25 e 68 dias. A média de idade dos animais com diarréia foi de $37 \pm 18$ dias. Infecção mista por Cryptosporidium foi encontrada em $75 \%$ (3/4) dos animais com diarréia. O tamanho dos cistos de Giardia $(\mathrm{n}=30)$ variou de 13 a $16 \mu \mathrm{m}$ de comprimento e 10 a $12 \mu \mathrm{m}$ de largura, média de 15 x $11 \mu \mathrm{m}$. Esses valores sugerem que os cistos eliminados pelas bezerras estão associados ao grupo morfológico de G. intestinalis (Olson et al., 1997). A maioria dos cistos era de forma ovóide e esporadicamente esféricos. Cinqüenta e cinco porcento das amostras (66/120) foram coletadas no período de seca (abril a setembro) e 45\% (54/120) no período chuvoso (outubro a dezembro). Das amostras de fezes com cistos de Giardia, 82\% (9/11) foram coletadas 
na estação chuvosa. O resultado deste estudo demonstrou, pela primeira vez, que a infecção por Giardia ocorre em bezerros no Brasil. Considerando que Giardia pode causar doença clínica em bezerros e que os organismos infectantes para os seres humanos e os ruminantes domésticos são morfologicamente e antigenicamente similares (Buret et al., 1990), e que os bezerros podem eliminar cistos de Giardia potencialmente infectantes para o homem (O'Handley et al., 2000), a presença dessa parasitose reveste-se de importante significado epidemiológico, e sugere que os bezerros naturalmente infectados podem servir de reservatório da infecção para o homem.

Palavras-chave: Bezerro, Giárdia spp.

\begin{abstract}
Fecal samples were collected from 50 female Holstein calves (1-90 days old) from a commercial dairy cattle farm located in Lavras, Minas Gerais, Brazil and examined for presence of Giardia cysts using the zinc sulfate flotation method. A total of 120 samples were collected from March 1999 to April 2000, and fecal consistency (normal or diarrheic) was noted prior to the examination for Giardia cysts. Giardia spp. cysts were found in 11 (9\%) of the 120 faecal samples of calves co-infected with Eimeria spp., in calves

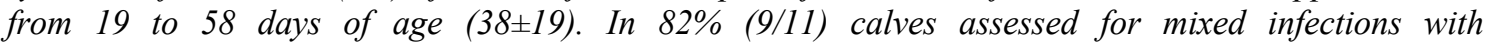
Cryptosporidium spp. and Giardia, oocysts of Cryptosporidium were found in three out of four diarrheic calves $(75 \%)$ positive for Giardia. Giardia cysts $(n=30)$ sized 13-16 $\times 10-12 \mu \mathrm{m}$ (mean of $15 \times 11 \mu \mathrm{m}$ ). They appeared to belong to the morphological group of $\mathrm{G}$. intestinallis according to the size and morphological characteristic of the cysts. This is the first detection of Giardia spp. in calves in Brazil. Considering that Giardia has the potential to cause clinical disease in calves and that organisms infecting humans and domestic ruminants are morphologically and antigenically similar, and calves can shed Giardia cysts potentially infective for humans, the parasite in calves may be of major epidemiological significance, and suggests that naturally infected calves may be reservoirs of Giardia infections for man.
\end{abstract}

Keywords: Calf, Giardia spp

\title{
REFERÊNCIAS BIBLIOGRÁFICAS
}

ADAM, R.D. The biology of Giardia spp. Microbiol. Rev., v.55, p.706-732, 1991.

BURET, A., denNHOLLANDER, N., WALLIS, P.M. et al. Zoonotic potential of giardiasis in domestics ruminants. J. Infect. Dis., v.162, p.231-237, 1990.

DIRKSEN, G., GRUNDER, H.D. STOBER, M.. Exame clínico dos bovinos. 3.ed. Rio de Janeiro: Guanabara Koogan, p.204-205, 1993.

KIRKPATRICK, C.E. Giardiasis. Vet. Clin. North Am. Small Anim. Pract.. v.17, p.1377-1387, 1987.

O'HANDLEY, R.M., OLSON, M.E., FRASER, D. et al. Prevalence and genotypic characterisation of Giardia in dairy calves from Western Australia and Western Canada. Vet. Parasitol., v.90, p.193-200, 2000.

OLSON, M.E., GUSELLE, N.J., O'HANDLEY, R.M. et al. Giardia and Cryptosporidium in dairy calves in British Columbia. Can. Vet. J., v.38, p.703-706, 1997.

XIAO, L., HERD, R.P., BOWMAN, G.L. Prevalence of Cryptosporidium and Giardia infections on two Ohio farms with different management systems. Vet. Parasitol., v.52, p.331-336, 1994.

XIAO, L., HERD, R.P., RINGS, D.M. Infection patterns of Cryptosporidium and Giardia in calves. Vet. Parasitol., v.51, p.41-48, 1993.

ZAJAC, A.M. Giardiasis. Compend. Contin. Educ. Pract. Vet., v.14, p.604-611, 1992. 